\title{
ANALISIS PENGARUH GAYA KEPEMIMPINAN OTORITER KEPALA DESA TERHADAP KINERJA APARATUR DESA PANGKALAN BULIAN BATANG HARI LEKO
}

\author{
Oleh : \\ Usailan Oemar \\ Rully Alamsyah \\ Reki Arisandi \\ Sekolah Tinggi Ilmu Ekonomi Rahmaniyah \\ Email : \\ usailanoemar@stier.ac.id \\ rullyalamsyah@stier.ac.id
}

\begin{abstract}
Authoritarian leadership is if power or authority, mostly absolute to leader or if the leader adheres to a centralized system of authority. Decision making and wisdom are only determined by the leader himself, subordinates are not included to give suggestion, idea, and consideration in the decision making process. His / her leadership just focused on increasing employee work productivity and And less attention to employees' feeling and walfare. The influence of authoritarian leadership style has affected toward the village aparatus job performance At Pangkalan Bulian Kecamatan Batang Hari Leko Musi Banyuasin regency showed low correlation (35.1\%) and positive toward the village aparatus job performance at PangkalanBulianKecamatanBatangHarilekoMusiBanyuasin regency, because $r$ value is in the range of $0.20-0.399$. It is also proven by seeing at $R$ Sequare that is 0.123 that is information that $12.3 \%$ of employees' job performance variable $(Y)$ is affected by authoritarian leadership style variable $(X)$ while The rest $87.7 \%$ is explained by other factors. Hypothesis test result ( $t$-test) between authoritarian leadership style toward employees job performance also showed that Ho Is rejected and $\mathrm{Ha}$ is accepted it means that authoritarian leadership style has affected toward village aparatus' job performance Pangkalan Bulian Kecamatan Batang Hari Leko Musi Banyuasin regency with A level of significance $<0.05$ that is 0.001 .
\end{abstract}

Keywords: Authoritarian leadership style, employees job performance

\section{PENDAHULUAN}

\section{Latar Belakang Masalah}

Hadirnya Undang-undang Desa akan terjadi perubahan konstalasi politik, hukum, ekonomi dan sosial pada pemerintahan desa di seluruh Indonesia. Dengan undang-undang tersebut pemerintahan desa punya dasar hukum yang jelas untuk mengakses sumber pendanaan dari APBD, APBN di samping pendapatan yang bersumber dari pendapatan asli desa guna menunjang pembangunan masyarakat di pedesaan. Dengan pemberian 
kewenangan yang lebih besar pemerintahan desa juga memiliki peluang untuk menentukan arah kebijakan dalam rangka mewujudkan kesejahteraan masyarakat.

Pada sisi lain terbitnya undang-undang desa juga merupakan tantangan bagi pemerintahan desa beserta segenap stakeholder untuk bisa mengolah sumber dana dan peluang yang besar itu, karena tidak secara otomatis dengan dana yang besar akan langsung terwujud kesejahteraan apabila tidak mampu mengelola secara baik. Agar terwujud pembangunan desa yang efektif dan efisien tentunya dibutuhkan perencanaan yang matang dengan memperhitungkan segenap potensi yang dimiliki, tim kerja yang profesional, pola pelaksanaan pembangunan yang tepat, pengawasan yang mampu menghindari kebocoran dan penyimpangan, serta adanya sistem pelaporan dan evaluasi yang transparan dan akuntabel. Apabila lima hal tersebut tidak bisa diwujudkan maka potensi sumber dana dan kewenangan yang besar tersebut akan menjadi sia-sia bahkan bias menjadi bencana. Untuk mewujudkan semua ini dibutuhkan sumber daya manusia terutama perangkat desa yang professional dari segi pendidikan, pengetahuan, dan ketrampilan sesuai tugas yang diembannya. Kondisi pemerintahan desa saat ini masih sangat lemah, hal ini disebabkan sistem pembangunan pemerintah sebelumnya yang bersifat top-down, hampir semua pembangunan direncanakan oleh pusat dan desa tinggal menerima perintah apa yang harus dilakukan.

Kepemimpinan merupakan suatu proses kegiatan seseorang untuk menggerakkan orang lain dengan memimpin, membimbing, mempengaruhi orang lain, untuk melakukan sesuatu agar dicapai hasil yang diharapkan (Kartono, 2012: 34), dari pengertian tersebut dapat dikatakan bahwa seorang pemimpin yang dalam hal ini kepala desa harus memiliki keahlian dalam meningkatkan kinerja bawahannya. Sedangkan Kinerja Pegawai adalah sebagai hasil dari prestasi kerja yang ditampilkan oleh pegawai tersebut dalam pelaksanaan tugas sehari-hari (Rusdi; 2011: 306). Karena mengingat tolak ukur dari keberhasilan suatu desa adalah dengan melibatkan semua elemen dari aparatur desa yang ada (Undang-undang nomor 6 tahun 2014). Aparatur desa yang dimaksud adalah perangkat desa, badan perwakilan desa, PKK, karang taruna, linmas dan LPM.

Disamping itu gaya kepemimpinan seorang kepala desa sangat berpengaruh terhadap kinerja perangkat desa yang ada selaku bawahannya, bagaimana mengambil keputusan, memotivasi pegawai, berkomunikasi dengan baik, mengendalikan bawahan, bertanggung jawab dan kemampuan mengendalikan emosi. Disamping itu hendaknya pemimpin harus bisa memberikan apresiasi terhadap kinerja yang telah dilakukan oleh bawahannya disamping itu, Salah satu tugas dari seorang Kepala Desa adalah bagaimana memberdayakan sumber daya manusia yang dimilikinya secara optimal. Pemberdayaan ini berarti mengupayakan agar sumber daya manusia itu mampu dan mau bekerja secara optimal demi tercapainya tujuan organisasi. Upaya tersebut dilakukan melalui proses manajemen terhadap sumber daya manusia dengan berbagai kegiatannya.

Dari pengamatan yang penulis temui dilapangan diketahui bahwa masih banyak Aparatur Desa yang bekerja tidak dengan sepenuh hati yang kesannya hanya formalitas saja, Aparatur Desa yang tidak tahu akan permasalahan yang ada di desanya, Aparatur Desa yang datang ke kantor hanya mengisi absen saja dan kemudian pulang, Aparatur Desa yang kurang peka jika ada masyarakat yang melapor akan permasalahan yang dihadapi masyarakat karena mereka merasa tidak dihargai oleh Kepala Desa. Hal ini disebabkan oleh Gaya kepemimpinan Kepala Desa yang cenderung bersifat otoriter yang penulis rasa tidak cocok untuk diterapkan diwilayah ini, hal ini dibuktikan dengan seringnya kepala desa yang tidak melibatkan perangkat desa dalam pengambilan keputusan-keputusan yang bersifat penting, kepala desa dalam mengambil keputusan cendrung tidak memperhatikan kepentingan rakyat banyak dan yang paling parah adalah kepala desa dalam pembuatan program hanya melibatkan orang-orang yang dianggapnya pro terhadap programnya.

Berdasarkan latar belakang permasalahan tersebut di atas, maka penulis tertarik 
untuk melakukan penelitian dengan judul " Analisis Pengaruh Gaya Kepemimpinan Otoriter Kepala Desa Terhadap Kinerja Aparatur Desa Pangkalan Bulian Kecamatan Batang Hari Leko Kabupaten Musi Banyuasin" 


\section{Rumusan Masalah}

Kondisi umum kinerja Perangkat Desa Pangkalan Bulian Kecamatan Batang Hari Leko Kabupaten Musi Banyuasin hubungannya dengan gaya kepemimpinan Kepala Desa, maka rumusan masalah dalam penelitian ini adalah Bagaimana pengaruh gaya kepemimpinan otoriter Kepala Desa terhadap kinerja Aparatur Desa Pangkalan Bulian Kecamatan Batang Hari Leko Kabupaten Musi Banyuasin?.

\section{Tujuan Penelitian}

Mengacu pada permasalahan tersebut di atas, maka tujuan yang hendak dicapai dalam penelitian ini adalah untuk mengetahui pengaruh gaya kepemimpinan otoriter terhadap kinerja Aparatur Desa Pangkalan Bulian Kecamatan Batang Hari Leko Kabupaten Musi Banyuasin.

\section{Manfaat Penelitian}

Adapun manfaat yang akan diharapkan dari penelitian ini adalah :

\section{Manfaat Teoritis}

Penelitian ini diharapkan dapat memperluas wawasan terhadap ilmu pengetahuan terutama dalam bidang Manajemen Sumber Daya Manusia, khususnya dalam kajian yang berhubungan dengan gaya kepemimpinan dan kinerja pegawai. Selain itu, penlitian ini diharapkan dapat bermanfaat bagi penelitian lain.

2. Manfaat Praktis

Dari aspek praktis kegunaan penelitian ini untuk mengetahui gaya kepemimpinan otoriter pengaruhnya terhadap kinerja pegawai sebagai masukan bagi Desa Pangkalan Bulian Kecamatan Batang Hari Leko Kabupaten Musi Banyuasin.

\section{LANDASAN TEORI}

\section{Gaya Kepemimpinan}

\section{1. Pengertian Gaya Kepemimpinan}

Organisasi pada dasarnya dipastikan akan memerlukan seorang pemimpin. Keberhasilan atau kegagalan sebuah organisasi terletak pada kepemimpinan. Kepemimpinan terdapat di segenap organisasi dan tingkat paling kecil sampai dengan tingkat yang lebih tinggi. Pemimpin sangat menentukan keberhasilan pekerjaan bawahannya dengan kepemimpinan dan partisipasinya. Menurut Sutrisno (2010: 213) kepemimpinan adalah suatu proses kegiatan seseorang untuk menggerakkan orang lain dengan memimpin, membimbing, mempengaruhi orang lain, untuk melakukan sesuatu agar dicapai hasil yang diharapkan. Sedangkan Indrawijaya (2010: 141) mengatakan kepemimpinan adalah kemampuan mempengaruhi dan menggerakan orang lain, sehingga mereka bertindak dan berperilaku sebagaimana diharapkan, terutama bagi tercapainya tujuan yang diinginkan. Kepemimpinan dapat pula dipandang sebagai suatu bentuk persuasi suatu seni pembinaan sekelompok orang tertentu, biasanya melalui pendekatan dan motivasi yang tepat sehingga mereka tanpa ada rasa takut untuk bekerja sama dalam mencapai tujuan organisasi. Peran kepemimpinan atasan dalam memberikan kontribusi pada karyawan untuk pencapaian kinerja yang optimal dilakukan melalui lima cara, yaitu

1) pemimpin mengklarifikasi apa yang diharapkan dari karyawannya, secara khusus tujuan dan sasaran dari kinerja mereka;

2) pemimpin menjelaskan bagaimana memenuhi harapan tersebut;

3) pemimpin mengemukakan kriteria dalam melakukan evaluasi dari kinerja secara efektif;

4) pemimpin memberikan umpan balik ketika karyawan telah mencapai sasaran, dan

5) pemimpin mengalokasikan imbalan berdasarkan hasil yang telah mereka capai.

\subsection{Indikator Gaya Kepemimpinan Otoriter.}


Menurut Sutikno (2010: 134) menyatakan sebagai berikut :

1. Kemampuan Mengambil Keputusan Pengambilan keputusan adalah suatu pendekatan yang sistematis terhadap hakikat alternatif yang dihadapi dan mengambil tindakan yang menurut perhitungan merupakan tindakan yang paling tepat, contohnya segala keputusan sendiri diambil oleh pimpinan

2. Kemampuan Memotivasi Kemampuan Memotivasi adalah daya pendorong yang mengakibatkan seorang anggota organisasi mau dan rela untuk menggerakkan kemampuannya (dalam bentuk keahlian atau keterampilan) tenaga dan waktunya untuk menyelenggarakan berbagai kegiatan yang menjadi tanggung jawabnya dan menunaikan kewajibannya, dalam rangka pencapaian tujuan dan berbagai sasaran organisasi yang telah ditentukan sebelumnya. Contohnya segala tugas bawahan diperinci oleh bawahan.

3. Kemampuan dalam bersikap dan berkomunikasi terhadap bawahan Adalah kecakapan atau kesanggupan penyampaian pesan, gagasan, atau pikiran kepada orang lain dengan tujuan orang lain tersebut memahami apa yang dimaksudkan dengan baik, secara langsung lisan atau tidak langsung. Contohnya dalam bersikap kepada bawahan, pemimpin melibatkan perasaan pribadinya, sehingga lebih bersifat subjektif.

4. Kemampuan dalam memberikan kesempatan memberikan kesempatan kepada bawahan, Pemimpin harus memiliki keinginan untuk membuat orang lain mengikuti keinginannya dengan menggunakan kekuatan pribadi atau kekuasaan jabatan secara efektif dan pada tempatnya demi kepentingan jangka panjang perusahaan. Termasuk didalamnya memberitahukan orang lain apa yang harus dilakukan dengan nada yang bervariasi mulai dari nada tegas sampai meminta atau bahkan mengancam. Tujuannya adalah agar tugas-tugas dapat terselesaikan dengan baik. Pemimpin yang memberikan kesempatan kepada bawahan untuk berpartisipasi atau mengajukan pendapat, tetapi hanya sebagai lips service saja.

5. Kemampuan Mengendalikan Pekerjaan Bawahan dengan ketat.

\subsection{Pengertian dan Syarat Perangkat Desa}

Sesuai dengan Undang-undang nomor 6 tahun 2014 tentang Desa Pasal 25 bahwa Pemerintah Desa adalah Kepala Desa atau yang disebut dengan nama lain dan yang dibantu oleh perangkat Desa atau yang disebut dengan nama lain. Dalam ilmu manajemen pembantu pimpinan disebut staf. Staf professional diartikan sebagai pegawai yntu pimpinan yang memiliki keahlian dalam bidangnya, bertanggungjawab, dan berperilaku professional dalam menjalankan tugasnya (Lembaga Administrasi Negara, 2009). Selanjutnya pada pasal 26 disebutkan; Kepala Desa bertugas menyelenggarakan Pemerintahan Desa, melaksanakan Pembangunan Desa, pembinaan kemasyarakatan Desa, dan pemberdayaan masyarakat Desa. Dengan demikian dapat disimpulkan bahwa Perangkat Desa adalah pembantu Kepala Desa dalam pelaksanaan tugas menyelenggarakan Pemerintahan Desa, melaksanakan Pembangunan Desa, pembinaan kemasyarakatan Desa, dan pemberdayaan masyarakat Desa.

Perangkat Desa diangkat oleh Kepala Desa setelah dikonsultasikan dengan Camat atas nama Bupati/ Walikota. Dalam melaksanakan tugas dan wewenangnya, perangkat Desa bertanggung jawab kepada Kepala Desa. Perangkat Desa diangkat dari warga Desa yang memenuhi persyaratan. Karena tugas pemerintah desa yang begitu berat maka perangkat desa harus memiliki kemampuan yang memadai untuk bisa mendukung kepala desa dalam menjalankan pemerintahan dan pembangunan.

\subsection{Pengertian Kinerja}

Kinerja pegawai merupakan aspek yang penting dalam manajemen sumber daya manusia beberapa pengertian yang dikemukakan dalam beberapa pandangan. Sedarmayanti (2014: 108) menyatakan bahwa kinerja merupakan sistem yang digunakan 
untuk menilai dan mengetahui apakah seorang karyawan telah melaksanakan pekerjaannya secara keseluruhan, atau merupakan perpaduan dari hasil kerja (apa yang harus dicapai seseorang) dan kompetensi (bagaimana seseorang mencapainya).

\subsection{Penelitian Terdahulu}

Penelitian Herlina Sari (2016) berjudul "Pengaruh Gaya Kepemimpinan Otoriter dan loyalitas terhadap kinerja perangkat desa di Desa Supat Kecamatan Babat Supat Kabupaten Musi Banyuasin. Hasil penelitian menemukan bahwa gaya kepemimpinan otoriter memiliki pengaruh fositif dan searah dalam mempengaruhi kinerja pegawai, sementara itu loyalitas dalam penelitian ini memiliki pengaruh yang kecil terhadap kinerja pegawai perangkat desa di Desa Supat Kecamatan Babat Supat Kabupaten Musi Banyuasin.

Penelitian Mohammad Rifqi Ramadhan (2014) yang berjudul "Peran Gaya Kepemimpinan dalam mempengaruhi kinerja bawahan pada Perangkat Desa Sidodadi Kecamatan Buleleng Jawa Timur". Hasil penelitian menemukan bahwa Perangkat Desa Sidodadi Kecamatan Buleleng Jawa Timur merupakan desa yang memiliki inisiatif dalam memenuhi seluruh kebutuhannya serta mampu menyelesaikan permasalahannya tanpa bergantung pada orang/instansi lain.

\section{Kerangka Pemikiran}

Kerangka pikir ini menggambarkan keterkaitan berbagai aspek yang mencerminkan kinerja pengaruh dan hubungannya dengan gaya kepemimpinan pada Desa Pangkalan Bulian Kecamatan Batang Hari Leko.

\section{Gaya Kepemimpinan (X)}

1. Segala keputusan sendiri diambil oleh pimpinan

2. Segala tugas bawahan diperinci oleh atasan

3. Pemimpin melibatkan perasaan pribadinya, sehingga lebih bersifat subjektif.

4. Pemimpin memposisikan bawahan sebagai lips service saja

5. Kemampuan Mengendalikan Pekerjaan Bawahan dengan ketat.

Sutikno (2010: 134)

\section{Gambar .1}

\section{Kerangka Pemikiran}

\section{Hipotesis Penelitian}

Berdasarkan latar belakang dan rumusan masalah yang ada maka penulis menyusun hipotesis yaitu:

Ho : Gaya kepemimpinan Otoriter Kepala Desa tidak berpengaruh terhadap kinerja Aparatur Desa Pangkalan Bulian Kecamatan Batang Hari Leko Kabupaten Musi Banyuasin.

Ha: Gaya kepemimpinan Otoriter Kepala Desa berpengaruh terhadap kinerja 
Aparatur Desa Pangkalan Bulian Kecamatan Batang Hari Leko Kabupaten Musi Banyuasin.

\section{METODELOGI PENELITIAN}

\section{Lokasi Penelitian}

Obyek penelitian ini adalah Perangkat Desa pada Desa Pangkalan Bulian Kecamatan Batang Hari Leko Kabupaten Musi Banyuasin. yang beralamat di Jalan Gas Conoco Phillips Suban-Gressik KM. 50 Dusun II Desa Pangkalan Kecamatan Batang Hari Leko Kabupaten Musi Banyuasin.

\section{Metode Penelitian}

Metode yang digunakan adalah metode kualitatif dan kuantitatif. Menurut Sanusi (2011: 104), "Metode kualitatif adalah metode yang menggunakan data yang berasal dari respon, penjelasan hubungan antar variable-variabel yang diteliti yang mempunyai keterkaitan dengan teori-teori yang dipakai dalam penelitian tersebut. Sedangkan metode kuantitatif adalah metode yang penjelasannya melalui formula/rumus secara matematis ataupun statistik, dengan perhitungan angka-angka".

\section{Populasi dan Sampel Penelitian}

\subsection{Populasi}

Populasi Menurut Sanusi (2011: 87), "Populasi adalah seluruh kumpulan elemen yang menunjukkan ciri-ciri tertentu yang dapat digunakan untuk membuat kesimpulan", Adapun populasi dalam penelitian ini adalah Aparatur Desa Pangkalan Bulian Kecamatan Batanghari Leko Kabupaten Musi Banyuasin sebanyak 76 orang.

\subsection{Sampel}

Sampel dalam penelitian ini adalah seluruh pegawai/ Perangkat Desa Pangkalan Bulian Kecamatan Batang Hari Leko Kabupaten Musi Banyuasin yang berjumlah 76 orang. Untuk itu teknik pengambilan sampel yang digunakan adalah sampel jenuh. Menurut Sugiyono (2009: 54), sampel jenuh adalah teknik pengambilan sampel bila semua anggota populasi digunakan sebagai sampel.

\section{Sumber Data}

Menurut sumbernya, data yang digunakan adalah data primer. Sugiyono (2009: 86), berupa data wawancara dan jawaban kuesioner para responden yang merupakan pegawai/ Perangkat pada Desa Pangkalan Bulian Kecamatan Batang Hari Leko Kabupaten Musi Banyuasin.

\section{Teknik Pengumpulan Data}

Pengumpulan data dengan menggunakan kuesioner yaitu dengan cara memberi seperangkat pertanyaan atau pernyataan tertulis kepada pegawai/ Perangkat Desa Pangkalan Bulian Kecamatan Batang Hari Leko Kabupaten Musi Banyuasin. Dari hasil kuesioner tersebut data yang didapat dianalisis secara kuantitatif, di mana skala yang digunakan dalam penelitian ini adalah skala Likert (Ghozali, 2009 :12)

\section{Teknik Analisis Data}

\subsection{Validitas}

Menurut Priyatno (2010: 90) adalah ketepatan atau kecermatan suatu instrumen dalam mengukur apa yang ingin diukur. Uji Validitas sering digunakan untuk mengukur ketepatan suatu item dalam kuisioner atau skala, apakah item-item pada kuisioner tersebut sudah tepat dalam mengukur apa yang ingin diukur. Dalam penelitian ini 
metode yang digunakan adalah dengan metode Bivariate Pearson (Korelasi Pearson Product Moment), antar skor butir pertanyaan/pernyataan lebih besar atau $t_{\text {hitung }}>r_{\text {table }}$ barulah dikatakan valid.

6.2. Uji Reliabilitas

Uji Reliabilitas menurut Priyatno (2010: 97) adalah Suatu pengujian untuk mengetahui konsistensi alat ukur, apakah alat pengukur yang digunakan dapat diandalkan dan tetap konsisten jika pengukuran tersebu diulang. Dalam penelitian metode yang digunakan adalah yang digunakan metode Cronbach's Alpha $>0,60$.

6.3. Analisis Regresi Linear Sederhana

$$
\mathrm{Y}=\mathrm{a}+\mathrm{b} \mathrm{X}+\mathrm{e} \quad \mathrm{a}=\frac{(\Sigma \mathrm{Y}-\mathrm{b} \cdot \Sigma \mathrm{X})}{\mathrm{n}} \quad \mathrm{b}=\frac{\mathrm{n} \cdot \Sigma \mathrm{XY}-(\Sigma \mathrm{X})(\Sigma \mathrm{Y})}{\mathrm{n} \cdot \Sigma \mathrm{X}^{2}-(\Sigma \mathrm{X})^{2}}
$$

Dimana :

Y = Kinerja Aparatur Desa Pangkalan Bulian Kecamatan Batang Hari Leko

Kabupaten Musi Banyuasin

$\mathrm{X}=$ Gaya Kepemimpinan Kepala Desa

$\mathrm{a}=$ Konstanta

b $=$ Koefisien Regresi

$\mathrm{n}=$ jumlah data

$\mathrm{e}=$ error terms

\subsection{Analisis Korelasi}

Analisa koefisien Korelasi yaitu uji yang menentukan derajat atau kekuatan korelasi antara kinerja pada Aparatur Desa Pangkalan Bulian Kecamatan Batang Hari Leko Kabupaten Musi Banyuasin (Y) dengan gaya kepemimpinan (X) pada Aparatur Desa Pangkalan Bulian Kecamatan Batang Hari Leko Kabupaten Musi Banyuasin.

Sugiyono (2014: 214) memberikan interpretasi koefesien korelasi sebagai berikut :

Tabel 1.

Interpretasi terhadap koefisien korelasi

\begin{tabular}{|l|l|}
\hline $0,00-0,199$ & Sangat Rendah \\
\hline $0,20-0,399$ & Rendah \\
\hline $0,40-0,599$ & Sedang \\
\hline $0,60-0,799$ & Kuat \\
\hline $0,80-1,000$ & Sangat Kuat \\
\hline
\end{tabular}

\section{Pengujian Hipotesis}

Untuk melihat pengaruh parsial dari masing-masing variabel bebas terhadap variabel terikat dapat dijelaskan dengan menggunakan uji t, adalah yang dilakukan secara satu persatu terhadap variable. Untuk menghitung besarnya t hitung digunakan rumus sebagai berikut :

$$
t=\frac{\mathrm{r} \sqrt{\mathrm{n}-2}}{\sqrt{1-\mathrm{r}^{2}}}
$$

Dimana: 
$\mathrm{t}=$ nilai hitung

$\mathrm{r}=$ koefisien korelasi

$\mathrm{n}=$ jumlah pengamatan

Adapun kriteria pengujiannya adalah :

Ho diterima : $\quad$ sig $\mathrm{t}>0,05$ dan $\mathrm{t}$ hitung $<\mathrm{t}$ tabel

Ho ditolak : $\quad$ sig $\mathrm{t} \leq 0,05$ dan $\mathrm{t}$ hitung $\geq \mathrm{t}$ tabel

Ho : Gaya kepemimpinan (X) tidak memiliki pengaruh dalam membentuk kinerja (Y) Aparatur Desa Pangkalan Bulian Kecamatan Batang Hari Leko

Ha : Gaya kepemimpinan (X) memiliki pengaruh dalam membentuk kinerja (Y) Aparatur Desa Pangkalan Bulian Kecamatan Batang Hari Leko

\section{PEMBAHASAN}

Distribusi Karekteristik Responden dan Jawaban Kuuesioner

\section{Distribusi Karekteristik Responden}

\section{a. Frekuensi Usia Responden}

Dalam Frekuensi ini dapat diketahui jumlah dari frekuensi usia responden dalam penelitian ini.

Tabel 2.

Frekuensi Usia Responden

\begin{tabular}{|c|c|c|c|c|c|}
\hline & & Frequency & Percent & $\begin{array}{c}\text { Valid } \\
\text { Percent } \\
\end{array}$ & $\begin{array}{c}\text { Cumulative } \\
\text { Percent }\end{array}$ \\
\hline \multirow[t]{6}{*}{ Valid } & $<25$ TAHUN & 5 & 6.58 & 6.58 & 6.58 \\
\hline & 26 - 30 TAHUN & 25 & 32.89 & 32.89 & 39.47 \\
\hline & 31 - 35 TAHUN & 18 & 23.68 & 23.68 & 63.16 \\
\hline & 36 - 40 TAHUN & 18 & 23.68 & 23.68 & 86.84 \\
\hline & > 41 TAHUN & 10 & 13.16 & 13.16 & 100,0 \\
\hline & Total & 76 & 100 & 100 & \\
\hline
\end{tabular}

Sumber : Data Primer (Diolah), 2018

Dari tabel di atas diketahui bahwa dari kebanyakan responden yang dominan dalam penelitian yang penulis lakukan adalah berusia 26-30 tahun dengan frekuensi sebanyak $32.89 \%$, berusia 31-35 tahun dan 36 - 40 tahun masing-masing sebanyak $23,68 \%$, responden yang berusia diatas 41 tahun berjumlah $13,16 \%$, dan responden yang berusia dibawag 25 tahun berjumlah 6.58\%. Dari data tersebut dapat dimaklumi mengingat bahwa usia tersebut merupakan usia produktif manusia dalam bekerja.

\section{b. Frekuensi Jenis Kelamin Responden}

Dalam Frekuensi ini dapat diketahui jumlah dari frekuensi jenis kelamin responden dalam penelitian yang penulis lakukan yaitu pegawai pada Aparatur Desa Pangkalan Bulian Kecamatan Batang Hari Leko Kabupaten Musi Banyuasin.

Tabel 3.

Frekuensi Jenis Kelamin Responden

\begin{tabular}{|ll|r|r|r|r|}
\hline & Frequency & Percent & Valid Percent & \multicolumn{1}{c|}{ Cumulative Percent } \\
\hline Valid & PEREMPUAN & 11 & 14.47 & 14.47 & 14.47
\end{tabular}




\begin{tabular}{|l|l|l|l|r|} 
LAKI-LAKI & 55 & 85.53 & 85.53 & 100,0 \\
Total & 76 & 100,0 & 100,0 & \\
\hline
\end{tabular}

Sumber : Data Primer (Diolah), 2018

Dari tabel di atas dapat kita lihat, bahwa jenis kelamin responden yang paling banyak adalah laki-laki yaitu 55 responden rendahkan jenis kelamin perempuan hanya 11 responden dari data diatas hal ini cukup dimaklumi mengingat jumlah Aparatur Desa Pangkalan Bulian Kecamatan Batang Hari Leko Kabupaten Musi Banyuasin lebih banyak laki-laki dengan perbandingan $1: 4$.

\section{c. Frekuensi Pendidikan Responden}

Dalam Frekuensi ini dapat diketahui frekuensi pendidikan yang menjadi responden dalam penelitian yang penulis lakukan yaitu Aparatur Desa Pangkalan Bulian Kecamatan Batang Hari Leko Kabupaten Musi Banyuasin.

Tabel 4.

Frekuensi Pendidikan Responden

\begin{tabular}{|ll|r|r|r|r|}
\hline & \multicolumn{1}{|c|}{ Frequency } & Percent & Valid Percent & Cumulative Percent \\
\hline Valid & sma & 43 & 56.57 & 56.57 & 56.57 \\
& s1 & 30 & 39.47 & 39.47 & 96,04 \\
& s2 & 4 & 3.96 & 3.96 & 100,0 \\
& Total & 76 & 100,0 & 100,0 & \\
\hline
\end{tabular}

Sumber : Data Primer (Diolah), 2018

Dari tabel di atas dapat dilihat, bahwa responden yang paling dominan adalah dengan latar belakang pendidikan SMA sebanyak 43 responden, S1 sebanyak 30 responden rendahkan untuk responden dengan latar belakang pendidikan S2 sebanyak 4 responden, hal ini cukup dimaklumi mengingat Aparatur Desa Pangkalan Bulian Kecamatan Batang Hari Leko Kabupaten Musi Banyuasin pendidikan SMA sangat dominan sebesar $64 \%$ dari jumlah dari jumlah responden.

\section{Distribusi Jawaban Responden}

Hasil jawaban 76 responden yang menjawab untuk pernyataan yang berhubungan dengan pengaruh gaya kepemimpinan otoriter kepala desa terhadap kinerja aparatur desa Pangkalan Bulian Kecamatan Batang Hari Leko Kabupaten Musi Banyuasin sebagai berikut:

1. Untuk pernyataan Pemimpin dapat mengambil keputusan dengan tepat yang menjawab ragu-ragu 19, 48 menjawab setuju dan sisanya 9 menjawab sangat setuju

2. Untuk pernyataan Ketika pemimpin mengambil keputusan, dan keputusan tersebut kurang tepat, pemimpin dapat dengan segera memperbaikinya dan meminta maaf kepada bawahan yang menjawab ragu-ragu 20, 48 menjawab setuju dan sisanya 8 menjawab sangat setuju.

3. Untuk pernyataan Pemimpin mendeskripsikan pekerjaan yang akan dikerjakan oleh bawahan yang menjawab ragu-ragu 4, 65 menjawab setuju dan sisanya 7 menjawab sangat setuju.

4. Untuk pernyataan Ketikab awahan tidak bekerja sesuai dengan keinginan pimpinan pimpinan dengan segera memperbaikinya sendiri, yang menjawab ragu-ragu 3, 60 menjawab setuju dan sisanya13 menjawab sangat setuju.

5. Untuk pernyataan Pemimpin menilai kinerja bawahan atas dasar sukadan tidak suka saja yang menjawab ragu-ragu 11, 48 menjawab setuju dan sisanya 17 menjawab sangat setuju. 
6. Untuk pernyataan Pemimpin memberikan pekerjaan kepada bawahan tidak sesuai dengan kemampuan bawahan yang menjawab ragu-ragu 4, 43 menjawab setuju dan sisanya 29 menjawab sangat setuju.

7. Untuk pernyataan Pemimpin tidak melibatkan bawahan dalam pengambilan keputusan yang menjawab ragu-ragu 5, 47 menjawab setuju dan sisanya 6 menjawab sangat setuju.

8. Untuk pernyataan Kebijakan yang ditetapkan pemimpin bersifat mutlak untuk dilaksanakan oleh semua bagian dari organisasi yang menjawab ragu-ragu 5, 41 menjawab setuju dan sisanya 30 menjawab sangat setuju.

9. Untuk pernyataan Pemimpin mengawasi pekerjaan bawahan dengan ketat yang menjawab ragu-ragu 4, 55 menjawab setuju dan sisanya 17 menjawab sangat setuju.

10.Untuk pernyataan Bawahan tidak suka bertentangan pendapat dengan pimpinan yang menjawab ragu-ragu 1, 56 menjawab setuju dan sisanya 10 menjawab sangat setuju.

Berdasarkan hasil jawaban responden untuk pernyataan yang berhubungan dengan kinerja aparatur desa Pangkalan Bulian Kecamatan Batang Hari Leko Kabupaten Musi Banyuasin sebagai berikut:

1. Untuk pernyataan Pegawai yang telah menjalankan tugasnya dengan baik, sehingga menghasilkan kualitas kerja yang sesuai dengan standar yang diharapkan yang menjawab ragu-ragu 15,53 menjawab setuju dan sisanya 8 menjawab sangat setuju.

2. Untuk pernyataan Kesalahan dalam menjalankan tugas rendah karena kinerja pegawai yang baik yang menjawab ragu-ragu 21,50 menjawab setuju dan sisanya 5 menjawab sangat setuju.

3. Untuk pernyataan Pegawai dalam bekerja sesuai dengan SOP yang telah ditetapkan yang menjawab ragu-ragu 2,67 menjawab setuju dan sisanya 7 menjawab sangat setuju.

4. Untuk pernyataan Kuantitas kerja masing-masing pegawai berbeda sesuai kemampuan pegawai yang menjawab ragu-ragu 2,66 menjawab setuju dan sisanya 8 menjawab sangat setuju.

5. Untuk pernyataan Setia pada ketidaksamaan program yang telah ditetapkan dengan yang terjadi di lapangan, yang mengakibatkan perubahan pengguna dana, pegawai selalu mengkoordinasikan dengan atasan yang menjawab ragu-ragu 5,51 menjawab setuju dan sisanya 17 menjawab sangat setuju.

6. Untuk pernyataan Pegawai menjalankan tugasnya dengan efisiensi biaya yang menjawab ragu-ragu 23,26 menjawab setuju dan sisanya 27 menjawab sangat setuju.

7. Untuk pernyataan Pekerjaan yang telah dibebankan kepada pegawai diselesaikan dengan tepat waktu yang menjawab ragu-ragu 6,50 menjawab setuju dan sisanya 2 menjawab sangat setuju

8. Untuk pernyataan Pegawai memanfaatkan waktu dalam bekerja dengan sebaikbaiknya yang menjawab ragu-ragu 8,41 menjawab setuju dan sisanya 27 menjawab sangat setuju.

9. Untuk pernyataan Pegawai memperhatikan keselamatan dalam bekerja yang menjawab ragu-ragu 10,49 menjawab setuju dan sisanya 17 menjawab sangat setuju.

10.Untuk pernyataan Pegawai memperoleh jaminan kesehatan dari atasan yang menjawab ragu-ragu 3, 53 menjawab setuju dan sisanya 20 menjawab sangat setuju.

\section{Hasil Pengujian}

\section{a. Regresi Linear Sederhana}

Pada analisis regresi sederhana ini yang dilakukan pengolahan data untuk 
mengetahui derajat keeratan antara variabel Gaya Kepemimpinan Otoriter terhadap variabel kinerja Aparatur Desa Pangkalan Bulian Kecamatan Batang Hari Leko Kabupaten Musi Banyuasin. Dari analisis data menggunakan perhitungan regresi berganda pada program SPSS 20. maka didapat hasil sebagai berikut:

Tabel 5.

Koefisien Regresi Sederhana

Coefficients. (a)

\begin{tabular}{|c|c|c|c|c|c|c|}
\hline \multicolumn{2}{|c|}{ Model } & \multicolumn{2}{|c|}{$\begin{array}{c}\text { Unstandardized } \\
\text { Coefficients }\end{array}$} & \multirow{2}{*}{$\begin{array}{c}\text { Standardized } \\
\text { Coefficients } \\
\text { Beta } \\
\end{array}$} & \multirow{2}{*}{$\frac{\mathrm{T}}{\mathrm{B}}$} & \multirow{2}{*}{$\begin{array}{c}\text { Sig. } \\
\text { Std. Error }\end{array}$} \\
\hline & & B & Std. Error & & & \\
\hline \multirow[t]{2}{*}{1} & (Constant) & 30.597 & 4.833 & & 6.331 & .000 \\
\hline & $\begin{array}{l}\text { GAYA } \\
\text { KEPEMIMPINAN } \\
\text { OTORITER }\end{array}$ & .432 & .128 & .351 & 3.378 & .001 \\
\hline
\end{tabular}

Sumber : Data Primer (Diolah), 2018

Dari tabel tersebut diatas maka didapat persamaan regresi sederhana sebagai berikut :

$Y=30,597+0,432 X$

Dimana :

$\mathrm{Y}=$ Kinerja pegawai

$\mathrm{X}$ = Gaya Kepemimpinan Otoriter

Interpretasi dari persamaan regresi mengenai pengaruh variabel Independent yaitu Gaya Kepemimpinan Otoriter terhadap variabel dependent yaitu kinerja Aparatur Desa Pangkalan Bulian Kecamatan Batang Hari Leko Kabupaten Musi Banyuasin dapat dijelaskan sebagai berikut :

- Nilai konstanta sebesar 30,597 menyatakan bahwa besarnya nilai variabel Y jika variabel bebasnya dianggap nol artinya tanpa dipengaruhi Gaya Kepemimpinan Otoriter maka besarnya kinerja Aparatur Desa Pangkalan Bulian Kecamatan Batang Hari Leko Kabupaten Musi Banyuasin adalah tetap sebesar 30,597.

- Koefisien regresi yaitu Gaya Kepemimpinan Otoriter (X) sebesar 0,432 menyatakan bahwa setiap terjadi penambahan Gaya Kepemimpinan Otoriter sebesar 1 satuan, maka hal tersebut akan mempengaruhi kinerja Aparatur Desa Pangkalan Bulian Kecamatan Batang Hari Leko Kabupaten Musi Banyuasin yakni sebesar 0,432. Koefisien bernilai positif artinya terjadi hubungan positif antara Gaya Kepemimpinan Otoriter dengan kinerja Aparatur Desa Pangkalan Bulian Kecamatan Batang Hari Leko Kabupaten Musi Banyuasin.

b Analisis Korelasi

Tabel 6.

Koefisien Korelasi

Model Summary (b)

\begin{tabular}{|l|l|l|l|l|}
\hline Model & R & R Square & Adjusted R Square & Std. Error of the Estimate \\
\hline
\end{tabular}




\begin{tabular}{l|r|r|r|r|}
\hline 1 & $.351(\mathrm{a})$ & .123 & .113 & 2.68465 \\
\hline a Predictors: (Constant), GAYA KEPEMIMPINAN OTORITER & & \\
b Dependent Variable: KINERJA
\end{tabular}

Sumber : Data Primer (Diolah), 2018

Dari perhitungan yang pengolahan datanya menggunakan program SPSS For Window Release 20 maka didapat nilai korelasi variabel independent 0.351 yang terdapat pada tabel Summary. Dari penafsiran terhadap koefisien korelasi tersebut dapat diketahui bahwa variabel Gaya Kepemimpinan Otoriter $(\mathrm{X})$ berkorelasi yang rendah terhadap kinerja Aparatur Desa Pangkalan Bulian Kecamatan Batang Hari Leko Kabupaten Musi Banyuasin, karena nilai $\mathrm{r}$ berada di rentang 0,20 - 0,399. Untuk mengetahui berapa besar hubungan tersebut dapat dilihat dari $R$ Sequare yaitu 0,123 yang memberikan pengertian bahwa $12,3 \%$ variabel kinerja pegawai $(\mathrm{Y})$ dipengaruhi oleh variabel gaya kepemimpinan otoriter (X) sedangkan sisanya 87,7\% dijelaskan oleh faktor lainya.

\section{c. Pengujian Hipotesis}

Tabel 7.

Koefisien Regresi Sederhana

Coefficients(a)

\begin{tabular}{|c|c|c|c|c|c|c|}
\hline \multirow[b]{2}{*}{ Model } & & \multicolumn{2}{|c|}{$\begin{array}{c}\text { Unstandardized } \\
\text { Coefficients }\end{array}$} & \multirow{2}{*}{$\begin{array}{c}\begin{array}{c}\text { Standardized } \\
\text { Coefficients }\end{array} \\
\text { Beta } \\
\end{array}$} & \multirow{2}{*}{$\mathrm{t}$} & \multirow{2}{*}{$\begin{array}{c}\text { Sig. } \\
\text { Std. Error } \\
\end{array}$} \\
\hline & & B & Std. Error & & & \\
\hline 1 & $\begin{array}{l}\text { (Constant) } \\
\text { GAYA } \\
\text { KEPEMIMPINA } \\
\text { N OTORITER }\end{array}$ & $\begin{array}{r}30.597 \\
.432\end{array}$ & 4.833 & .351 & 6.331 & .000 \\
\hline
\end{tabular}

a Dependent Variable: KINERJA

Sumber : Data Primer (Diolah), 2018

Dari nilai t hitung diatas secara parsial dapat diketahui bahwa t hitung 3,378. sedangkankan $\mathrm{t}$ tabel diketahui dengan tabel distribusi dengan derajat kebebasan (df) n-k1 sehingga diketahui $t$ tabel adalah 1,675; t hitung 3,378>t tabel 1,675 maka Ho ditolak sehingga dapat diketahui bahwa Gaya Kepemimpinan Otoriter berpengaruh rendah terhadap kinerja Aparatur Desa Pangkalan Bulian Kecamatan Batang Hari Leko Kabupaten Musi Banyuasin.

\section{Hasil Penelitian}

Berdasarkan hasil pembahasan di atas pengaruh Gaya Kepemimpinan Otoriter berpengaruh rendah terhadap kinerja Aparatur Desa Pangkalan Bulian Kecamatan Batang Hari Leko Kabupaten Musi Banyuasin menunjukkan berkorelasi yang bersifat rendah $(35,1 \%)$ dan positif terhadap kinerja Aparatur Desa Pangkalan Bulian Kecamatan Batang Hari Leko Kabupaten Musi Banyuasin, karena nilai r berada di rentang 0,20-0,399.

Hal tersebut juga dibuktikan dengan dilihat dari $R$ Sequare yaitu 0,123 yang memberikan pengertian bahwa 12,3\% variabel kinerja pegawai (Y) dipengaruhi oleh variabel gaya kepemimpinan otoriter (X) sedangkan sisanya $87,7 \%$ dijelaskan oleh faktor lainya.

Hasil uji hipotesis (uji t) antara gaya kepemimpinan otoriter terhadap kinerja pegawai juga menujukkan bahwa Ho ditolak dan Ha diterima yang berarti bahwa Gaya Kepemimpinan Otoriter berpengaruh terhadap kinerja Aparatur Desa Pangkalan Bulian 
Kecamatan Batang Hari Leko Kabupaten Musi Banyuasin dengan tingkat signifiknasi $<0,05$ yaitu sebesar 0,001 .

\section{SIMPULAN DAN SARAN}

\section{Simpulan}

Dari hasil pembahasan pada di atas sebelumnya dapat disimpulkan:

1. Pada uji validitas, sumua item pertanyaan dalam penelitian ini adalah valid artinya semua item dapat digunakan lebih lanjut untuk penelitian selanjutnya.

2. Dari hasil pengolahan data, didapat koefisien alpha hitung $\mathbf{0 , 6 5 3 9}$ untuk variabel Gaya Kepemimpinan Otoriter (X). Hal tersebut menandakan bahwa semua variabel utama pada kuesioner adalah reliabel atau dapat diandalkan karena nilai reliabilitas diatas 0,6 dan dikuatkan juga dengan nilai CITC diatas 0,226 ( $\mathrm{r}$ tabel).

3. Pada Uji secara regresi, nilai konstanta sebesar 30,597 menyatakan bahwa besarnya nilai variabel Y jika variabel bebasnya dianggap nol artinya tanpa dipengaruhi Gaya Kepemimpinan Otoriter maka besarnya kinerja Aparatur Desa Pangkalan Bulian Kecamatan Batang Hari Leko Kabupaten Musi Banyuasin adalah tetap sebesar $30,597$.

4. Koefisien korelasi sebesar $\mathbf{0 , 3 5 1}$ menandakan bahwa terdapat hubungan yang rendah antara Gaya Kepemimpinan Otoriter terhadap kinerja Aparatur Desa Pangkalan Bulian Kecamatan Batang Hari Leko Kabupaten Musi Banyuasin. Disamping itu koefisien determinasi sebesar $\mathbf{0 , 1 2 3}$ menunjukkan bahwa variabel gaya kepemimpinan Otoriter dalam penelitian ini mampu menjelaskan $12.30 \%$ terhadap kinerja Aparatur Desa Pangkalan Bulian Kecamatan Batang Hari Leko Kabupaten Musi Banyuasin. Artinya dalam penelitian ini gaya kepemimpinan otoriter memiliki pengaruh terhadap Kinerja sebesar 12,30 sedangkan sisanya yaitu 87,7\% dipengaruhi oleh faktor lain yang tidak diteliti dalam penelitian ini.

5. Dari hasil penelitian yang penulis lakukan diketahui bahwa variabel independen (gaya kepemimpinan otoriter) memiliki pengaruh terhadap variabel dependend (kinerja) aparatur desa Pangkalan Bulian Kecamatan Batang Hari Leko. Hal dibuktikan dari uji regresi maupun uji korelasi. Dari tingkat signifikansipun dapat diketahui bahwa semua variabel signifikan artinya dalam penelitian ini semua variabel independen berpengaruh terhadap variabel dependent

6. Dari nilai t-hitung diatas secara parsial dapat diketahui bahwa t-hitung 3,378. sedangkankan $\mathrm{t}$ tabel diketahui dengan tabel distribusi dengan derajat kebebasan (df) n-k-1 sehingga diketahui t tabel adalah 1,675 maka Ho ditolak sehingga dapat diketahui bahwa Gaya Kepemimpinan Otoriter berpengaruh rendah terhadap kinerja Aparatur Desa Pangkalan Bulian Kecamatan Batang Hari Leko Kabupaten Musi Banyuasin.

\section{Saran}

Saran-saran yang bisa dikemukakan penulis setelah melakukan penelitian ini sebagai berikut:

1. Pimpinan sebagai pengambil keputusan hendaknya dapat mengelelola konflik dengan baik, mengingat konflik ini jika dikelola dengan baik akan menimbulkan dampak yang positif, tapi apabila tidak dikelola dengan baik akan mengakibatkan permasalahan yang timbul dalam suatu organisasi, disamping itu permasalahan keadilan hendaknya menjadi perhatian lebih bagi pimpinan, mengingat dari kuisioner yang telah penulis bagikan bahwa responden banyak yang merasakan perbedaan perlakuan oleh pimpinan. Manajemen konflik yang ada dalam suatu 
organisasi perlu ditingkatkan lagi pelaksanaannya karena hal ini sepele tapi memiliki manfaat yang sangat besar bagi kelangsungan suatu organisai yang dalam hal ini adalah Desa Pangkalan Bulian Kecamatan Batang Hari Leko Kabupaten Musi Banyuasin.

2. Hendaknya pimpinan lebih memperhatikan faktor-faktor apa saja yang mempengaruhi Kinerja Aparatur Desa Pangkalan Bulian Kecamatan Batang Hari Leko Kabupaten Musi Banyuasin, banyak hal yang mempengaruhi kinerja pegawai selain Gaya Kepemimpinan Otoriter, masalah kenyaman akan pekerjaaan yang telah dibebankan pimpinan kepada pegawai merupakan hal yang perlu mendapatkan perhatian serius oleh pimpinan, karena pegawai yang nyaman akan pekerjaan yang telah dibebankan kepada mereka akan memiliki kinerja yang baik dan begitu juga sebaliknya. Kinerja yang tinggi biasanya berpengaruh positif terhadap pencapaian kinerja yang baik pada organisasi.

\section{DAFTAR PUSTAKA}

Anoraga.2010, Manajemen Sumber Daya Manusia. Cetakan keempat puluh.BPFE, Yogyakarta.

Hasibuan, Malayu. 2012. Manajemen Sumber Daya Manusia. Cetakan kedepalan. PT BumiAksara, Jakarta.

Heidjrachman.2012. Organisasi Perusahaan dan Sumber Daya Manusia.Terjemahan. Jakarta: Erlangga.

Indrawijaya. 2010. PsikologiIndustri, Seri Umum. Sumber Daya Manusia. Edisi 4. Liberty, Yogyakarta.

Kartono, Ahmad. 2012. PemimpindanKepemimpinan. Jakarta: PT. RajawaliGrafindoPersada.

Mangkunegara, A.A. Anwar Prabu.2011. Manajemen Sumber Daya Manusia Perusahaan. Remaja Rosda Karya, Bandung.

Notoatmodjo. 2012. Perilaku Organisasi. PT Indeks, Kelompok Gramedia, Jakarta.

Priyatno, Duwi. 2010. Paham Analisa Statistik Data.(EdisiPertama). CetakanPertama. Yogyakarta: BukuSeru.

Rivai, Veitzhal.2011. Manajemen Sumber Daya Manusia Untuk Perusahaan Dari Teorike Praktik.PT Rajagrafindo Persada, Jakarta.

Rusdi, SalehSiregar. 2011. PengantarSumberDayaManusia. Yogyakarta: UPP AMP YKPN.

Sanusi, Anwar. 2011. StatistikdanMetodologiBisnis. Yogyakarta, STIE Harapan.

Sedarmayanti.2014. Manajemen Organisai dan Manajemen Sumber Daya Manusia. Cetakan kedepalan. PT BumiAksara, Jakarta.

Siagian, Sondang P. 2011. Manajemen Sumber Daya Manusia, Jakarta: PT. BumiAksara.

Sugiyono.2012. Memahami Penelitian Kulitatif dan Kuantitatif secara professional. PT. Indoturbine Jakarta.

Sutrisno.Edy. 2013. Manajemen Sumber Daya Manusia. EdisiPertama. Jakarta: Kencana

Thoha, Miftah. 2013. Prilaku Organisasi Konsep Dasar Dan Implikasinya. Jakarta: PT. Raja GrafindoPersada.

Umar, Husein. 2011. MetodeRisetPerilakuOrganisasi. GramediaPustakaUtama, Jakarta.

Undang-Undang Nomor 6 tahun 2014. 
Widjaja, Amin. 2013. Perusahaan, Organisasi, dan Pengawasan.Edisi Keempat. Harvarindo. Jakarta 